\title{
Christmas and Christmastide in the Interpretation of Russian Writers of the XVIII- XX Centuries
}

Elena M. Luludova ${ }^{+}$

\section{Abstract}

New Year and Christmas are widely represented in the world literature. This is both a special genre - a touching Christmas story, which is created according to certain canons, and traditional "scary stories", the action of which is timed to the "magic" period of Christmas, and a description of the merry winter holidays in Soviet children's literature, where the New year replaced the rejected Christmas. But not only the storytellers and romantics have left a description of the holidays they loved since childhood on the pages of their literary works. Poets, satirists, and realists had a hand here - quite a wide range of authors who described both the New Year holiday itself and everything that happens on Christmas. The ceremonies that took place during these holidays have a deep meaning. Therefore, the main purpose of the work is a comparative analysis of the descriptions of the Nativity and the Nativity in the works of Russian writers of the XVIII-XX centuries. The author analyses the works of Gogol, Tolstoy, Bulgakov, Starygin, Zaitsev. It has been established that Russian literature actively turned to Christmas and Christmas holidays in the nineteenth century. For example, A.S. Pushkin in "Eugene Onegin" contrasted Christmas with Christmas. It has been established that Christian motifs dominate heathenism in Gogol's Christmas tale. In the novel "War and Peace" by L.N. Tolstoy was able to subtly determine the originality of the Christmas mood in the popular understanding. It has been determined that in classical works of Russian literature, Christmas time appears more often than Christmas: the pagan tradition is "one's own", original, unlike Christian. The atmosphere is transmitted by writers more attractively than the Christmas one.

Keywords: Folk Tradition, Feminism, Novel, Christmastide Stories, Symbolism

\footnotetext{
${ }^{\dagger}$ Department of Social and Cultural Technologies, Almaty Branch of Saint-Petersburg University of Humanities and Social Sciences, 050004, 9/11 Chaykovskiy Str., Almaty, Republic of Kazakhstan, Email: eluludova@mail.ru (C) 2018 Luludova. This is an Open Access article distributed under the terms of the Creative Commons Attribution License (http://creativecommons.org/licenses/by/2.0), which permits unrestricted use, distribution, and reproduction in any medium, provided the original work is properly cited.
} 


\section{Introduction}

Quite often in classic works of Russian literature of the XVII-XX centuries, one or other holidays are mentioned. If you use the words of S. S. Averintsev, "the world of archaism and the world of civilization actively explain each other" (Averintsev, 1970: 117). The most frequent and detailed descriptions are made Christmas or Christmastide. Already in Old Russian chronicles, it was customary to relate events to church holidays: the military defeat of Russians on such a day was seen as the punishment of the Lord for sins, victory - as the mercy of God. So, in the "Homily" of Vladimir Monomakh (XII century), it is said that at Christmas the prince managed to defeat the Polovtsians with God's help (Likhachev and Dmitriyev, 1978).

One of the first Christmastide stories was narrated in the Old Russian "The Tale of Frol Skobeyev". It was on the Christmastide when Frol managed to implement his daring plan. The stolnik's daughter Annushka arranged a party for the girls. In order to enter the house and "to have compulsory love" with Annushka, adventurer Frol dressed up in a girl's gown. According to S.V. Maksimov, "Christmastide gatherings $\langle\ldots\rangle$ differ from all other gatherings by the fact that both boys and girls dress up" (Maksimov, 1995: 480). However, "only the most brisk dress up in unusual clothes: the guys - in the women's clothing, the girls - in the men's suit" (Maksimov, 1995: 480). Perhaps some fear of dressing up was because the church disapproved of this custom. The mask was an element of a pagan cult: it was used in initiation rituals, in funeral rites (to ensure the return of souls exactly to their bodies), in the totem meaning (allowed members of the tribe to identify themselves with their ancestors) (Tresidder, 1999). In general, "the oldest meaning of the symbolism of the mask is that it expressed supernatural power" (Tresidder, 1999: 214).

From the people's point of view, "one of the mandatory moments of folk-festive fun was a disguise, that is, the renewal of clothes and their social image" (Bakhtin, 1990). The monument of the XVII century conveyed the spirit of the transitional era with the help of Christmastide images. They can be characterised by the words of $M$. Bakhtin: "Grotesque images with their essential attitude to the temporary change and with their ambivalence become the main means of artistic and ideological expression of that powerful sense of history and historical change, which arose in the Renaissance with exceptional strength" (Bakhtin, 1990). In medieval life, the symbolism of disguise was very common: different social groups had their corporate outfits; therefore, they changed their clothes when moving from one social position to another (for example, when taking monastic vows) (Ponyrko, 1977). Thus, the "sinful" Christmastide dress up were set against disguise, which was regulated by rules and certified the social status of a person.

The change of clothes by Frol Skobeyev is a Christmastide demonstration of freedom from feudal restrictions and norms. The hero transformed thrice, eventually removing the mask: "the man depicting the girl" - "the man in the clothes of the girl plays the role of the groom" - "man". Meanwhile, the purpose of the Christmastide change of clothes of Frol - is to change the social situation, get into the privileged strata of society, "dress up" in fact, according to the law.

Unlike the Christmastide pagan tradition, the hero dominates the story and not the heroine. Annushka got the role of the bride, that is, the girl remains herself. At the same time, the very idea of having fun at the Christmastide belonged to the heroine. As a result, she also took a festive, new, status of a married woman. According to O. Weininger, "a woman is not social", "a family is not a social institution" (Weininger, 1997: 198).

Russian literature actively appealed to Christmas and Christmastide holidays in the XIX century. A.S. Pushkin in "Eugene Onegin" opposed the Christmas to Christmastide. On the Christmas holiday, he spoke ironically, as of a boring duty, which must be performed "according to the custom of the people", "so that in the rest of the year they do not think 
about us" (Pushkin, 1986: 247), and in the description of the Christmastide, you can feel the festive mood which is felt by all the people, youth and old age are next to each other (Pushkin, 1986).

In the novel story of Tatyana, the Christmastide is one of the important links. Like everything around, she is captured by a sense of near transformation. This is a manifestation of her freedom, a tribute to emancipation (Pushkin, 1986).

\section{The Night Before Christmas in the Interpretation of N. V. Gogol}

In the story "The Night before Christmas" Gogol timed events to the eve of the church holiday, and not to the Christmastide, which, on the one hand, served as the basis of the new tradition, on the other - attracted attention to what was already known. Moreover, the heroine of Christmastide story and the hero of the Christmas story are antagonists when compared. Firstly, the heroine's activity is limited to the holiday. A hero of the Christmas story is active not only on holiday but also in the official and serious routine. It is no accident that Vakula's constant qualities are piety and theopathy. O. Weininger, in his work based on Christian principles, wrote that "piety is a purely masculine virtue" (Weininger, 1997: 120). He also referred self-observation, as well as guilt realisssation and repentance to purely masculine traits (Weininger, 1997). The researchers pointed to the elements of the life tradition in Gogol's story: like St. Anthony of Novgorod, Vakula overcame the devil with the help of the sign of the cross and travelled for one night (Mann, 1988).

In the story by Gogol, the church is mentioned three times. Moreover, Vakula appears in all three cases. In the beginning, it is said about the painting on the church wall, where the blacksmith portrayed the devil in such a funny way that the Evil One swore to take revenge. Then, already at Christmas, in the church during the festive service, "all the laity noticed that the holiday did not seem like one; that people feel missing something" (Gogol, 1984). The night before Christmas is Vakula's test, which he overcomes, returning to normal life. In Christmastide story, a woman tempts time, fate, a man. At Christmas, the hero turns out to be an examinee.

Secondly, a woman beyond the Christmastide festivity will be punished by the fact that she will be separated from her beloved. Stubborn Vakula won Oksana, who was laughing at the blacksmith and at the same time upset the dreams of his mother, the witch Solokha, about the prosperous house of Cossack Chub, Oksana's father.

Thirdly, the heroine in the Christmastide story is free and erotically directed to the future. In the Christmas story, on the contrary, the motif of fear is connected with the image of Vakula. This is natural: "Seriousness <...> is official, authoritarian, combined with violence, prohibitions, restrictions. In such seriousness, there is always an element of fear and intimidation" (Bakhtin, 1990). In folk tradition, a man is afraid of change and renewal (Bakhtin, 1990), before woman giving birth to new and young. He is afraid of a woman as of his "body grave" (Bakhtin, 1990). In the Gogol story, the masculine element was ultimately stronger than the female one.

However, the woman, remaining true to paganism, is connected with the devil: "At the very time when the blacksmith was preparing to be decisive, an evil spirit carried the laughing image of Oksana before him" (Starygina, 1998: 108). The image of a devil is of pre-Christian origin (Meletinsky, 1996). From Christianity, this is a personification of pagan vestiges. Thus, Vakula tries to solve two tasks that contradict each other simultaneously. He wants to conquer a woman and to resist the devil. Yu. Mann built another logical "chain": "It turns out that Vakula rushes to Patsyuk (who is somewhat "akin to the devil") for salvation from love, and to God - for salvation from the devil" (Mann, 1988: 25).

Vakula, the hero of the Christmas story, feels that he is contradicting himself, that is why both God and devil seem terrible to him. Let us compare. To get rid of fear, Vakula tries various ways. To get the best of the devil, he resorted 
first to the means of the people's tradition - to laughter. However, the devil attached himself to Vakula precisely because the artist put him to ridicule. Then he used the Christian method (the imposition of the cross), which was more effective. Having sinned against God, the smith also resorts to church rites - confession and repentance: he decides "from the present day $<\ldots>$ to bow fifty times through the whole year" (Gogol, 1984).

In the finale of the story, the nasty devil painted by Vakula is used to scare the children: "Women, as soon as the child was crying in their arms, brought it to the picture and said: "Here, look, at this painted muck!" - and the child, holding tears, clung to his mother's chest after looking at the picture" (Gogol, 1984: 131). According to Yu. Mann, this is one of the episodes proving that in work by Gogol the carnival beginning is complicated by strengthening the moments of a terrible and incomprehensible future in perspective (Mann, 1988). Apparently, Gogol's image is closer to another, Christian, symbolism. According to it, "in each child the soul slumbers, which, knowing the fragility of this world, soars to God" (Bauer et al., 1995: 205). D. Tresidder notes: "Christ pointed to the child as the one who can enter the Kingdom of God through its humility (Matthew 18: 3)" (Tresidder, 1999). In Christianity, "the medieval devil is a symbol of unaccountable fear, disordered chaos" (Bauer et al., 1995: 198).

Thus, Christian motifs dominate in the Christmas story by Gogol. However, Yu. Mann interprets the idea of the work in the spirit of dualism: "In whatever comic or ugly light the 'enemy of the human race' appears, only the intervention of the oppositely directed higher power can provide him with sufficient opposition" (Mann, 1988). So, if a woman, remaining a pagan, participates in Christmastide story, then the man joins the struggle of Christianity with paganism and becomes a character in the Christmas story.

\section{A Christmastide Plot in the Works by L. N. Tolstoy}

In the second half of the XIX century, the Christmastide story became one of the episodes of "War and Peace". Like its predecessors, L.N. Tolstoy was in search of a compromise between paganism and Christianity. According to M. Gorky's memoirs, "the thought that, most noticeably, sharpens his heart, is the thought of God" (Gorky, 1983: 147). D.S. Merezhkovsky argued that Leo Tolstoy was a "great pagan" in his artistic work; that he belongs to the Christians- pagans, "Christians before Christ" (Merezhkovsky, 1991: 138).

In the second volume of Tolstoy's novel, according to the principle of compositional symmetry, two Christmastide situations are described with the participation of the same heroines - Natasha and Sonya, but with an interval of four years. The Christmastide of 1806 the Family of the Rostovs spends in the city, in Moscow, and the Christmastide of 1810 - in the village. Regardless of the place and conditions of celebration in both cases, it is Natasha and Sonya who are at the centre of what is happening. However, the Christmastide of 1806 is marked by the fact that "never before in the Rostovs' house the love air, the atmosphere of love, did not make themselves felt with such force as on these days of holidays" (Tolstoy, 1984). Both Sonya and Natasha receive an offer of marriage. It is on the Christmastide that the young heroines first go to the "real" ball where the woman is considered a queen: "Both of them were particularly happy and cheerful that evening" (Tolstoy, 1984). As befits heroines of a Christmastide story, Natasha and Sonya decide their destiny.

However, contrary to the law of Christmastide, according to which the love initiative comes from a woman, neither of the girls will agree to a marriage. "The dowerless orphan" Sonya, in love with Nikolay Rostov, refused a very profitable match. Fourteen-year-old Natasha seriously, as an adult, rejected the matchmaking of the old, compared to her, 
Denisov. The "urban" and "village" Christmastide stories of L. Tolstoy are not only similar but also contrast.

In the Christmastide episode of "War and Peace", dress up becomes the main motive. Dressing allowed the heroes to become free: "Strange, but funny pas, which the dancers made out, once and for all decided that if they are dressed up, then no one would recognise them, and therefore they were not embarrassed" (Tolstoy, 1984). According to N. Julien, "outfitting plays the role of protection and gives anonymity, favourable for getting rid of depression and fear" (Julien, 1999).

Nikolay Rostov chose the costume of the old lady, Natasha - the hussar, Sonya - the Circassian. All these heroes, having changed their clothes, moved to the opposite sex: the man - to the female, both girls - to the male. The chain of metamorphosis turned out to be closed, forming a circle. The end is identical to the beginning. Male and female beginnings are inseparable, complement each other, constitute the whole. The culminating moment is the moment of a secret love meeting between the disguised Sonya and Nikolay in the garden behind the house. In the Christmastide suits, they still form a pair of "he and she".

The hero and heroines change places for a while, leaving a serious world, where everyone occupies a certain place. Wearing a mask is, firstly, a way of identification with what it embodies (Julien, 1999), and, secondly, an attempt to transform reality by the will of the imagination (Julien, 1999). On the other hand, "the choice of the preferred type of personality, the most desired mask with all its supposed changes and liberation, also reveals the hidden tendencies of the human psyche that cannot manifest itself in everyday life" (Julien, 1999: 242). Nikolay, obeying maman with his enthusiasm and uncertainty, did not choose the outfit of the old lady casually. If we agree with $\mathrm{K}$. Jung that "a mask is that, which a person is not, but for what they themselves and other people accept this person" (Averintsev, 1970: 129), then the Christmastide costume allows the hero to express his true essence.
Thus, the heroines disguise themselves to influence fate. Their costumes assume an active type of behaviour. 0 . Weininger remarked: "Appearance is the ' $\mathrm{l}$ ' of a woman" (Weininger, 1997). In his opinion, it is the woman who can change infinitely. Disguised girls seem "strange, pretty and strange people with thin moustaches and eyebrows" to Nikolay Rostov (Tolstoy, 1984). The leading motif of female images in the perception of the hero is duality: to Nikolay "it seemed that only now he fully recognised her for the first time, thanks to these plug-in whiskers. Sonya was really cheerful that evening, lively and good, which Nikolay had never seen her before" (Tolstoy, 1984: 295). Sonya "is quite different and still the same" for Nikolay (Tolstoy, 1984). He feels fascinated in the Christmastide world: "This Circassian with a mustache - I do not know who it is, but I love her" (Tolstoy, 1984: 292). The hero does not recognise the familiar places.

The motif of the moon in the Christmastide scenes becomes recurrent, symbolising the boundless power of the feminine principle. Nikolay peers "at Sonya in this strange moonlight, while looking in the same everchanging light from under eyebrows and moustache for that same former and present Sonya, with whom he has decided not to part from now on" (Tolstoy, 1984: 297). Even his sister suddenly attracts him with his femininity.

The moon not only connects the sky and the earth with its light but also "turns" them, changing places. At the Christmastide, the earthly principle dominates the heavenly: "The chest seemed to breathe not air, but some eternally young strength and joy" (Tolstoy, 1984: 296). The earth symbolises motherhood and fertility (Tresidder, 1999; Julien, 1999).

After the dress up, the heroines returned to themselves: "Undressing, but not erasing the corkscrew moustache, they sat for a long time talking about their happiness. They talked about how they will live being married, how their husbands will be friendly and how they will be happy" (Tolstoy, 1984: 298). It is in Natasha's words that the motif of fear appears: 
"- Only when will all of this happen? I'm afraid that never <...> It would be too good! - said Natasha, getting up and coming to the mirrors" (Tolstoy, 1984: 298). Divination - the transition from the holiday to weekdays: neither Natasha nor Sonya saw anything in the mirror. Their Christmastide dreams were not destined to come true. The wedding of Natasha and Prince Andrew will be upset. Nikolay would not be able to get his mother's consent to his marriage with Sonya.

\section{Christmastide Stories}

In the second half of the XIX century, the genre of the Christmastide story appeared in Russian literature. N.N. Starygina considers the primary genre-forming sign of the Christmastide story to be "the embodiment of the Christian soul arrangement, which determines the educationally moralizing character of the narrative" (Starygina, 1998: 172). One of the secondary genre-forming features is the "confinement of the action to the Christmas holidays - Christmastide or one Christmas night" (Starygina, 1998: 172). A child was often the character and addressee of the Christmastide stories, whose image occupies an important place in the symbolism of Christianity. In Christmastide stories, the antithesis of Christmastide and Christmas is removed.

However, in the Russian literature of the early $X X$ century, which expressed the complex social and cultural situation of the transition from one era to another, the Christmastide holiday is again contrasted with the Christmas one. Thus, in one of the most famous novels by B. Zaitsev, "The Blue Star" (1918), Christmas Day is a triumph of orderliness: "As in a good old house, Christmas at Vernadsky's passed according to an exact ritual: on the first day there were priests, who sang "Christmas Thine, O Christ our God"; Natalia Grigoriyevna fed them with ham, treated them with crockery, Madeira, and those vague and kind conversations that are usually conducted in such cases" (Zaitsev, 1989: 115). The regulation of the holiday is estimated from the point of view of the people's tradition, that is, negatively: "It was ceremonious and boring" (Zaitsev, 1989: 115).

On the contrary, the Christmastide is unpredictable. A decisive meeting between the hero and the heroine takes place on the evening of the Christmastide. Mashura, a girl who, from her early childhood, was ordered to be disciplined and serious, suddenly went to Khristoforov. The heroine behaves obeying the ancient tradition, but the hero violates the laws of the holiday. So, he takes a woman's privilege to read fortune at Christmas. Though, Khristoforov does not read fortune for himself, but for Mashura, and at her request.

However, he rejects the possibility of earthly love, refuses a woman on Christmastide: "You came to my room, Mashura, into an empty room <...> And you will leave. The room remains as before. I will stay. Without you" (Zaitsev, 1989: 118). There are notable echoes of pantheism in the image of the hero, which was characteristic by B. Zaitsev's works from the early period (Zaitsev, 1989). Khristoforov worships the star: "For me,, it is beauty, truth, deity. Besides, it is a woman. Moreover, it sends me the light of love" (Zaitsev, 1989: 119). At the same time, the Christian motifs are connected with the character: "The name of Khristoforov $\langle. .$.$\rangle is realized simultaneously$ both as a "new Christ" and as a "Christ-bearer". The Greek "Khristofor" is a Christ-bearer, martyr, servant of Christ" (Tresidder, 1999: 14). It turns out that he treats Mashura as the Virgin Mary.

The atmosphere of discord and discordant of transitional time is transmitted in the novel "The Blue Star". The noisy Moscow Christmastide masquerade ends with a duel. This image-metaphor: "the whole of Moscow" flies to its own destruction.

As in B. Zaitsev's novel, it is the woman who is capable of acting in "The White Guard" (192527) by M. Bulgakov. "The White Guard" by M. Bulgakov - is a "Christmas" novel. The novel begins in mid-December, when "the glimmer of Christmas was felt on the snowy streets" (Bulgakov, 1992). Despite the social upheavals of 1918 , which destroyed the old order of life, 
the Turbins family expects a Christmas holiday. V. Lakshin called M. Bulgakov "a militant archaist", the adherence to the past for whom is characteristic (Bulgakov, 1992). The novel by M. Bulgakov is a farewell to the passing epoch. Its attributes are an autocracy, Orthodoxy, faith in God and the afterlife (Bulgakov, 1992). Meanwhile, as V. Lakshin noted, "in the first novel by Bulgakov there is no break with the traditional religious consciousness, but there is no sense of loyalty to it" (Bulgakov, 1992: 27).

Bulgakov's heroine actively acts not on Christmastide, but at Christmas. Desperate Elena prays before the icon of the Virgin. When Elena gives up her husband before the icon, as though she gives the most precious that she has to the Virgin. At the same time, she transcends the pagan law of the triumph of the flesh, choosing brother, not husband. Moreover, the very name of the heroine causes pagan associations that go back to the Greek myth, primarily. Bulgakov's woman is the guardian of customs, but not of pagan, but of Christian ones. It was she who saw the vision of Christ: "Absolutely inaudible came the one, to whom Elena cried through the intercession of a swarthy maiden. He appeared next to the ravaged tomb, completely risen, and blessed, and barefooted" (Bulgakov, 1992: 411).

As in "The Blue Star", the heroine of "The White Guard" remains alone. However, unlike the novel by B. Zaitsev, she herself broke the pagan tradition, sacrificing her husband. At the same time, in Bulgakov's work, a woman's beginning is associated with life and overcoming death, which corresponds to the popular festive tradition.

If the events in "The White Guard" take place on Christmas, then in the play "The Days of the Turbins" (1926) the culmination is on The Eve of Theophany. This is the end of Christmastide when festive fun reaches its apogee. Elena is different here. It was that evening when Shervinsky proposed to her. As it is supposed by tradition, the Christmastide story by Bulgakov has a love colouring. Elena seems to have a magical power that attracts men. It is not accidental that the keynote of Elena's image is the red hair colour. This attribute is diachronically associated with representations about the other world (Smirnov, 1977).

The heroine negatively evaluates the potential groom. In her assessment, Shervinsky proves to be a dual: his looks are opposed to the inside: "Well, the trinkets are adjutant, he is as pretty as a cherub. And nothing more. And a voice" (Bulgakov, 1992). "You are a famous scoundrel" (Bulgakov, 1992). "The liar with the aiguillettes" (Bulgakov, 1992). Shervinsky's uncertainty was expressed in the fact that Elena speaks of him in the neuter gender: "Ugh, cunning, cowardly creature!" (Bulgakov, 1992). It is no coincidence that the heroine compares the hero to the snake. In general, the symbolism of the snake is ambiguous: this animal can manifest itself from both good and bad sides (Tresidder, 1999; Julien, 1999). According to this tradition, the snake is the seducer of Eve. Elena tells Shervinsky: "He stuck like a snake" (Bulgakov, 1992). In the house of Turbins, Shervinsky appears suddenly, immediately after the departure of Elena's husband.

In the Christmastide story by M. Bulgakov not the heroine, but the hero is involved in dress up. Shervinsky changed his clothes several times throughout the play. In the beginning, he, the adjutant of the hetman, appears in a burka and a "magnificent" Circassian coat. In the story of relations between Elena and Shervinsky, a romantic tradition of the XIX century is parodied, which goes back to the medieval knightly worship of the Beautiful Lady. Liar Shervinsky behaves gallantly: he gives Elena a huge bouquet of roses, says compliments, which she calls militaristic. He promises to sit at Elena's feet all night - in a burka. At the same time, in Shervinsky's words, you can hear echoes of the feminism ideas: "You are beautiful, intelligent, intellectually developed as they say" (Bulgakov, 1992: 30). Thus, two cultural traditions collide the old, the chivalricromantic, and the new, emancipatory.

\section{Conclusion}

Thus, summarising all of the above mentioned, it should be noted that Christmastide and Christmas images in Russian literature are a 
sign that the work was created in a transitional, unstable era. The hero achieves his goal in both Christmastide and Christmas stories, the heroine - only in the Christmas story of the beginning of the $X X$ century. Christmas and Christmastide images of the literature of the XIX century correspond to the Christian and folk festive traditions, and the images of the end of the XVII and the beginning of the XX century - violate them.

Also, in classical works of Russian literature, Christmastide appears more often than Christmas: the pagan tradition is "own", primordial as opposed to Christian. The Christmastide atmosphere is conveyed by writers more attractively than the Christmas one. However, the heroine of the Christmastide story cannot charm her chosen one so that he remains with her after the end of the holiday. It is because of the influence of Christianity with its negative attitude towards women and popular culture. By folk tradition, the woman actively acts in the literary Christmastide story of the XIX century (Pushkin and L. Tolstoy) and the beginning of the $X X$ century (B. Zaitsev). On the contrary, the man "intercepts" the initiative on Christmastide and seeks the desired in the Russian literature of the XVII and early XX centuries ("The Tale of Frol Skobeyev" and "The Days of the Turbins" by M. Bulgakov). Violation of the people's traditions, apparently, indicates a profound social change.

\section{References}

Averintsev, S.S. (1970). "Analytical Psychology" of K.-G. Jung and the laws of creative imagination. Questions of Literature, 3, pp. 113-143.

Bakhtin, M.M. (1990). Creativity of F. Rabelais and folk culture of the Middle Ages and the Renaissance. Moscow: Khudozhestvennaya literatura, pp. 32, 94, $104,265,269$.

Bauer, V., Dumots, I., Golovin, S. (1995). Encyclopedia of symbols. Moscow: KronPress, pp. 198, 205.
Bulgakov, M. (1992). Collected works. Moscow: Khudozhestvennaya literatura, pp. 23, 27, $182,411$.

Gogol, N.V. (1984). Selected works. Moscow: Khobbi, otdykh i sport, pp. 129, 131

Gorky, M. (1983). Literary portraits. Moscow: Molodaya gvardiya, p.147

Julien, N. (1999). Dictionary of symbols. Chelyabinsk: Ural LTD, pp. 134-135, 143, 241, 242.

Likhachev, D., Dmitriyev, L. (1978). Monuments of the literature of Ancient Rus: XI - the beginning of the XII century. Moscow: Khudozhestvennaya literature, p. 470.

Maksimov, S.V. (1995). Impure, unknown and godly power. Smolensk: Rusich, pp. 480.

Mann, Yu. (1988). Poetics of Gogol. Moscow: Khudozhestvennaya literature, pp. 24-25

Meletinsky, Ye.M. (1996). Mythology: Illustrated encyclopedic dictionary. St. Petersburg: Leningradskaya Galereya, p. 766

Merezhkovsky, D.S. (1991). Lev Tolstoy and the Church. Still water; Articles and studies of different years. Moscow: Sovetskiy pisatel', p.138

Ponyrko, N.V. (1977). Russian Christmastide of the XVII century. Leningrad: TODRL, pp. 84-100.

Pushkin, A.S. (1986). Compositions. Moscow: Khudozhestvennaya literature, pp. 262, 471

Smirnov, I.P. (1977). Old Russian laughter and the logic of the comic. Leningrad: TODRL, p. 308

Starygina, N.N. (1998). History of Russian literature of the second half of the XIX century. Moscow: Khudozhestvennaya literature, pp. 108, 172

Tolstoy, L.N. (1984). Collected works. Moscow: Khobbi, otdykh i sport, pp.48, 51-52, 294, 292, 295, 296, 297, 298 
Tresidder, D. (1999). Dictionary of symbols. Zaitsev, B. (1989). St. Nicholas Street: Tales and Moscow: Fair Press, pp. 14, 109, 116, 214. Stories. Moscow: Khudozhestvennaya Weininger, O. (1997). Gender and character. literatura, pp. 6-7, 115, 118, 119.

Basic research. Moscow: Latard, 120, 193, 197, 198. 